\title{
Toxic Air in the Industrial Corridor? An Analysis
}

\author{
Brittany Tarufelli ${ }^{1,}$ \\ ${ }^{a}$ Louisiana State University, 93 South Quad Dr., Baton Rouge, LA 70803, USA
}

\begin{abstract}
The Gulf Coast has gained a foothold as a low-cost region for chemical production. In this study, I leverage the arguably exogenous shock to natural gas prices and proximity to the Port of South Louisiana as instrumental variables to identify the impact of industrial development on air pollution and respiratory morbidity. I find that a $\$ 1$ decrease in natural gas prices decreased $\mathrm{PM}_{10}$ pollution by $44 \%$ of the sample average, but these effects decreased with proximity to the Port. Switching to natural gas as a feedstock improved pollution and health outcomes, but pollution exposure in industrial corridors remains an issue.

Keywords: Health, Energy, Environmental Economics

JEL classification: I1, Q4, Q5
\end{abstract}

\section{Introduction}

Access to cheap shale gas and international ports have spurred an industrial boom in Louisiana. Cheap shale gas cut feedstock prices for manufacturers, leading to significant investment in industrial projects in South Louisiana. But the increase in industrial activity - primarily centered around plastic, chemical, fertilizer, and liquified natural gas (LNG) plants - has come with costs. Particularly concerning is the potential for increased air pollution, in a region already heavily populated with chemical processing facilities and oil refineries.

While the factories that populate the Mississippi River Industrial Corridor (Industrial Corridor) — which occupies a stretch of the Mississippi River from Baton Rouge to New Orleans - have received national attention for potentially causing increased rates of cancer among certain communities, much less attention has been paid to the potential for respiratory morbidities, such as asthma, due to the air pollution caused by this industrial activity.

In 2017, chronic lower respiratory disease was the 4th highest cause of death in Louisiana 11 With one in 10 Louisianans coping with asthma at some point in their lives, it is one of the largest health burdens in the state ${ }^{2}$ Because asthma is caused by both genetic and environmental factors, outdoor air pollution can

\footnotetext{
${ }^{*}$ Corresponding author

1 https://www.cdc.gov/nchs/pressroom/states/louisiana/louisiana.htm (accessed 9/10/2020).

2 https://ldh.la.gov/index.cfm/page/2613 (accessed 9/10/2020).
} 
trigger and exacerbate the condition. Research has shown that exposure to particulate matter $\left(\mathrm{PM}_{10}\right.$ and $\left.\mathrm{PM}_{2.5}\right)$, ozone $\left(\mathrm{O}_{3}\right)$, nitrogen dioxide $\left(\mathrm{NO}_{2}\right)$, sulfur dioxide $\left(\mathrm{SO}_{2}\right)$, and carbon monoxide $(\mathrm{CO})$ increase respiratory symptoms, induce changes in lung function, and increase healthcare use in children and adults (Guarnieri and Balmes, 2014).

Although research suggests that pollution has a significant impact on respiratory morbidity, there is still much uncertainty about the magnitude of its effects. Because air pollution is not randomly assigned, it is challenging to disentangle pollution exposure from many potential confounding factors - such as socioeconomic status, lifestyle choices, weather and other environmental factors, as well as steps people take to avoid pollution exposure - that also affect respiratory morbidity and health outcomes. In addition, quantifying a community's pollution exposure is difficult, and often subject to measurement error.

How the shale revolution impacted industrial development in Louisiana poses a unique opportunity to identify the short-run effects of air pollution on respiratory morbidity (asthma), while accounting for potential confounding factors and the potential for measurement error in pollution concentrations. To address these identification challenges, I use annual data on natural gas prices and river barge calls at the Port of South Louisiana as instrumental variables for a parish's exposure to particulate matter (PM10) pollution.

Natural gas prices are an appealing instrument for several reasons. First, natural gas prices experienced an exogenous shock due to the development of fracking and horizontal drilling techniques that increased the supply of natural gas, causing a quick decline in natural gas prices. Fuel switching from other fossil fuels to natural gas as a primary feedstock affects pollution levels as natural gas is cleaner burning than other fossil fuels. Second, cheap shale gas spurred a boom of industrial activity that was concentrated in South Louisiana, potentially impacting pollution concentration levels in some communities differentially more than others.

River barge traffic at the Port of South Louisiana is also an appealing instrument for several reasons. First, the Port of South Louisiana occupies over 50 miles of the Industrial Corridor in St. James, St. John the Baptist, and St. Charles Parish. Over 60 facilities - the majority from oil and gas, petrochemical and chemical industries - are located along the port for easy access to international ports. Second, barge traffic is representative of Louisiana's industrial sector, with over half of total throughput comprising crude oil, petrochemicals, chemicals, and fertilizers - suggesting shifts in river barge traffic are also correlated with shifts in pollution at the Port. My data confirm that both natural gas prices and river barge traffic significantly affect $\mathrm{PM}_{10}$ pollution concentration levels. Important to my identification strategy, my data also confirm that the impacts to pollution increase with proximity to the Port.

Natural gas prices and river barge calls represent shifts in pollution, but because associated industrial activities could potentially affect county (parish) health outcomes through improving socioeconomic conditions or access to healthcare, I condition my instruments on a variety of variables to control for potential confounding factors. I include parish-level fixed effects to control for persistent differences in parish-level income and local economic conditions that affect pollution and health; national gross domestic product (GDP) or year fixed effects and annual time trends to control for annual shocks and long run trends that 
affect pollution, industrial activity, and health; as well as controls for weather which can affect natural gas consumption, pollution, and health. After conditioning on these control variables, I show that my results are generally robust to different confounding variable specifications, giving strength to the argument that my instruments are plausibly exogenous and uncorrelated with other unobserved determinants of health. I provide several tests of robustness to ascertain this assumption.

My approach is similar to Moretti and Neidell (2011), who identify the effect of increased ozone pollution from the Port of Los Angeles on respiratory-related emergency room visits. Different from Moretti and Neidell (2011), I focus on the impact of the shale revolution on health outcomes in Louisiana, identifying my results from the unique impacts to Louisiana parishes' air pollution concentrations, driven by the decline in natural gas prices as well as barge activity in the Port of South Louisiana. I condition my instruments and regressions on various fixed effects (similar to Beatty and Shimshack (2014)) to assess the strength of my instruments in controlling for potentially confounding factors with respect to pollution and health. My contribution is unique as this is the first study, to my knowledge, to address the effect of the shale revolution on health outcomes across a wide swath of communities, pinpointing the causal effect of PM10 exposure on asthma-related hospitalizations.

I find that that a $\$ 1$ increase in natural gas prices increases $\mathrm{PM}_{10}$ pollution concentration by $1.39 \mu \mathrm{g} / \mathrm{m}^{3}$, or $44 \%$ of the sample average $\mathrm{PM}_{10}$ pollution concentration. A one standard deviation increase in annual barge traffic - roughly 4,000 barges - increases $\mathrm{PM}_{10}$ pollution concentration by $1.26 \mu \mathrm{g} / \mathrm{m}^{3}$, or $40 \%$ of the sample average. Further, these effects increased with proximity to the Port of South Louisiana. With respect to the effect of PM10 pollution on asthma-related hospitalizations, I find that my IV estimates are roughly twice as large as OLS estimates, emphasizing the importance of disentangling pollution exposure from other confounding variables in determining health outcomes. A one $\mu \mathrm{g} / \mathrm{m}^{3}$ increase in parish-level PM10 concentration results in 12 additional hospitalizations, or a more than $12 \%$ increase in parish-level asthma hospitalizations, costing Louisiana asthma sufferers an additional $\$ 1.2$ million per year.

The United States, and in particular the Gulf Coast region has gained a foothold as a low-cost region for chemical production due to the shale revolution. My findings are relevant to local, state, and national policies that address how growing demand for industrial development, in particular demand for petrochemicalsincluding plastics - affect human health outcomes. Although shifting from other fossil fuels to natural gas as a feedstock has generated some improvements in pollution and health outcomes, more work needs to be done to address pollution concentrations in industrial areas. Other clean energy technologies, such as carbon capture utilization and storage (CCUS), energy efficiency, and some forms of industrial demand response provide opportunities to further reduce pollution and improve health outcomes for industrial communities 3

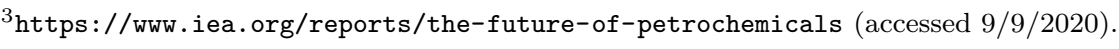




\section{Background on Air Pollution Regulations}

The Clean Air Act of 1970 (1970 CAA) paved the way for comprehensive regulation of air pollution at the federal and state level, with monitoring and enforcement primarily under the jurisdiction of the EPA. The 1970 CAA established the National Ambient Air Quality Standards (NAAQS) which set air quality standards for six criteria pollutants - ground level ozone, particulate matter, carbon monoxide, sulfur dioxide, nitrogen dioxide, and lead - that have been shown to harm health and the environment. As shown in Table 1, the maximum amount of criteria pollutants allowed in outdoor air by NAAQS have become more stringent over time, reducing the allowable amounts of harmful pollutants in the air. Particularly relevant to this study are Bush and Obama administration revisions for $\mathrm{PM}_{2.5}, \mathrm{NO}_{2}, \mathrm{SO}_{2}$, and $\mathrm{O}_{3}$, which reduced the amount of allowable pollution for these criteria pollutants from $2000-2015$.

\begin{tabular}{|c|c|c|c|c|c|}
\hline & $\overline{~(1)}$ & 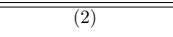 & $\overline{~(3)}$ & $\overline{~(4)}$ & $\overline{~(5)}$ \\
\hline Pollutant & Year & Averaging Time & Allowable Level & Final Rule/Decision & Measurement \\
\hline \multirow[t]{5}{*}{$\mathrm{PM}_{10}$} & 1997 & Annual & $50 \mu \mathrm{g} / \mathrm{m}^{3}$ & 62 FR 38652 & Annual arithmetic mean, averaged over 3 years \\
\hline & 1997 & 24 hour & $150 \mu \mathrm{g} / \mathrm{m}^{3}$ & 62 FR 38652 & 98th percentile, averaged over 3 years \\
\hline & 2006 & Annual & None & $71 \mathrm{FR} 61144$ & Annual $\mathrm{PM}_{10}$ NAAQS was revoked \\
\hline & 2006 & 24 hour & $150 \mu \mathrm{g} / \mathrm{m}^{3}$ & $71 \mathrm{FR} 61144$ & Not to be exceeded more than once per year on average over a 3 -year period \\
\hline & 2012 & 24 hour & $150 \mu \mathrm{g} / \mathrm{m}^{3}$ & 78 FR 3085 & Not to be exceeded more than once per year on average over a 3 -year period \\
\hline \multirow[t]{6}{*}{$\mathrm{PM}_{2.5}$} & 1997 & Annual & $15 \mu \mathrm{g} / \mathrm{m}^{3}$ & 62 FR 38652 & Annual arithmetic mean, averaged over 3 years \\
\hline & 1997 & 24 hour & $65 \mu \mathrm{g} / \mathrm{m}^{3}$ & 62 FR 38652 & 98th percentile, averaged over 3 years \\
\hline & 2006 & Annual & $15 \mu \mathrm{g} / \mathrm{m}^{3}$ & $71 \mathrm{FR} 61144$ & Annual arithmetic mean, averaged over 3 years \\
\hline & 2006 & 24 hour & $35 \mu \mathrm{g} / \mathrm{m}^{3}$ & $71 \mathrm{FR} 61144$ & 98th percentile, averaged over 3 years \\
\hline & 2012 & Annual & $12 \mu \mathrm{g} / \mathrm{m}^{3}$ & 78 FR 3085 & Annual arithmetic mean, averaged over 3 years \\
\hline & 2012 & 24 hour & $35 \mu \mathrm{g} / \mathrm{m}^{3}$ & 78 FR 3085 & 98th percentile, averaged over 3 years \\
\hline \multirow[t]{4}{*}{$\mathrm{CO}$} & 1994 & 1 hour & $35 \mathrm{ppm}$ & $59 \mathrm{FR} 38906$ & Maximum, not to be exceeded more than once in a year \\
\hline & 1994 & 8 hour & $9 \mathrm{ppm}$ & $59 \mathrm{FR} 38906$ & Maximum, not to be exceeded more than once in a year \\
\hline & 2011 & 1 hour & $35 \mathrm{ppm}$ & 76 FR 54294 & Maximum, not to be exceeded more than once in a year \\
\hline & 2011 & 8 hour & $9 \mathrm{ppm}$ & 76 FR 54294 & Maximum, not to be exceeded more than once in a year \\
\hline \multirow[t]{3}{*}{ Nitrogen Oxides } & 1996 & Annual & $53 \mathrm{ppb}$ & $61 \mathrm{FR} 52852$ & Annual arithmetic average \\
\hline & 2010 & Annual & $53 \mathrm{ppb}$ & 75 FR 6474 & Annual arithmetic average \\
\hline & 2010 & 1 hour & $100 \mathrm{ppb}$ & 75 FR 6474 & 98th percentile, 1 -hour daily maximum, averaged over 3 years \\
\hline \multirow{5}{*}{ Sulfur Dioxide } & 1996 & Annual & $0.03 \mathrm{ppm}$ & $61 \mathrm{FR} 25556$ & Annual arithmetic average \\
\hline & 1996 & 24 hour & $0.14 \mathrm{ppm}$ & $61 \mathrm{FR} 25556$ & Not to be exceeded more than once per year \\
\hline & 2010 & Annual & None & 75 FR 35520 & Annual $\mathrm{SO}_{2} \mathrm{NAAQS}$ was revoked \\
\hline & 2010 & 24 hour & None & 75 FR 35520 & Annual $\mathrm{SO}_{2}$ NAAQS was revoked \\
\hline & 2010 & 1 hour & $75 \mathrm{ppb}$ & 75 FR 35520 & 99th percentile, averaged over 3 years \\
\hline \multirow[t]{3}{*}{ Ozone } & 1997 & 8 hours & $0.08 \mathrm{ppm}$ & 62 FR 38856 & Annual fourth-highest daily maximum 8 -hr concentration, averaged over 3 years \\
\hline & 2008 & 8 hours & $0.075 \mathrm{ppm}$ & 73 FR 16483 & Annual fourth-highest daily maximum 8 -hr concentration, averaged over 3 years \\
\hline & 2015 & 8 hours & $0.070 \mathrm{ppm}$ & $80 \mathrm{FR} 65292$ & Annual fourth-highest daily maximum 8-hr concentration, averaged over 3 years \\
\hline
\end{tabular}

Criteria pollutants are regulated by federal and state governments due to their effect on human health and the environment. The link between adverse human health outcomes and exposure to criteria pollutants has been well-documented in the literature ${ }^{4}$ since the 1970s, when Holland et al. (1979) documented that high levels of particulate matter and other air pollution pose hazards to human health. In subsequent literature, researchers found evidence of hazards to human health from even relatively low concentrations of air pollution (Dockery and Pope, 1994). Particularly relevant for this study, in a survey of the literature on the effects of particulate air pollution, Pope, Dockery and Schwartz (1995) concluded that elevated levels of particulate air pollution are associated with increased risk of respiratory disease, including asthma, and increased risk of cardiopulmonary mortality. However, Dockery and Pope (1994) did not find acute effects with respect to cancer or other nonpulmonary and noncardiovascular causes of mortality due to particulate matter pollution.

${ }^{4}$ See Holland et al. (1979), Dockery and Pope (1994), Pope, Dockery and Schwartz (1995), Wilson et al. (1996), Wang et al. (1997), Ross (2009). 
Establishing conclusive links between pollution and human health outcomes is difficult, as the ideal experiment would be a controlled clinical experiment which exposes humans to pollution, a study that is, in practice, unethical (Beatty and Shimshack, 2014). Neverthless, Ross (2009) established likely causal links for long-term and short-term exposure to $\mathrm{PM}_{2.5}$ and respiratory effects, and causal links for long-term and short-term exposure to $\mathrm{PM}_{2.5}$ and cardiovascular effects, although similar links for exposure to $\mathrm{PM}_{10}$ were not sufficient to infer causality ${ }^{5}$

\section{Literature}

My study is related to an extensive literature that examines how air pollution impacts human health outcomes. One stream of this literature encompasses epidemiological research designs, which tend to establish correlation between air pollution and human health outcomes. The most common approach in this stream of literature is to use cohort-based longitudinal studies of adults (Pope, 1989, Dockery et al. 1993, Pope, Thun, Namboodiri, Dockery, Evans, Speizer and Heath, 1995: Pope et al., 2002, Clancy et al., 2002, Peters, 2005, Gauderman et al., 2007, Jerrett et al., 2009, Sheffield et al., 2011), although time series analyses or cross-sectional analyses are also common. Studies in this literature typically use a two step research design in which individual health outcomes are first regressed on community indicator variables and confounding individual covariates, then the estimated community fixed effects (relative risks) are regressed on long-term community-level average pollution exposure (Chay and Greenstone, 2003 Beatty and Shimshack, 2014).

An important takeaway in this literature is that controlling for other determinants of health, besides pollution exposure, is challenging. Most studies compare health outcomes across space or time, based on exposure to different levels of pollution. Because air pollution is not randomly assigned, other factors which can affect health outcomes - such as socioeconomic status, dietary and lifestyle factors, weather and environmental factors, as well as pollution avoidance behavior - must be taken into account. Further, pollution exposure, often assigned to communities or individuals based on their location using various interpolation techniques, is subject to measurement error.

To address these potential pitfalls, another stream of literature establishes causality of pollution on human health outcomes by controlling for other confounding factors, besides air pollution, that could potentially affect health outcomes. In this literature, three designs are commonly used to estimate the impact of exposure to air pollution on human health outcomes: using detailed survey data to link individual exposure to self-reported health outcomes, natural experiments or instrumental variables designs (Gallagher et al. 2010; Lleras-Muney, 2010; Neidell, 2010, Moretti and Neidell, 2011, Greenstone and Hanna, 2014, Knittel et al., 2016; Deschenes et al., 2017), or fixed effects designs (Chay and Greenstone, 2003; Neidell, 2004; Janke et al. 2009, Neidell, 2009; Beatty and Shimshack, 2014).

My research design is most similar to Moretti and Neidell (2011) who expound on the idea that avoidant

\footnotetext{
${ }^{5}$ These findings remain valid today, based on the most recent Intregrated Science Assessment for Particulate Matter, available at https://cfpub.epa.gov/ncea/isa/recordisplay.cfm?deid=347534 (accessed 1/11/2021).
} 
behavior and measurement error in pollution data can result in understated estimates of health outcomes due to pollution exposure. To account for these issues, they instrument for ozone levels using boat traffic at the Port of Los Angeles. They find that increases in ozone from boat traffic increase hospital costs by $\$ 44$ million annually. Similar to Moretti and Neidell (2011), I use an instrumental variables approach to help account for unobserved factors that influence both pollution and health outcomes, as well as address measurement error in pollution estimates. Different from Moretti and Neidell (2011), I identify my results based on variables that shift pollution in Louisiana, natural gas prices and river barge traffic, while assessing the strength of my instruments to various confounding parish-level and annual factors that could influence both pollution and health outcomes.

My study is also germaine to the literature that examines how particulate matter pollution impacts morbidity, specifically respiratory diseases. Pope $(1989)$ found that months with average $\mathrm{PM}_{10}$ levels that exceeded $50 \mu \mathrm{g} / \mathrm{m}^{3}$ were correlated with increased average admissions for children and adult hospitalizations for respiratory illnesses, including asthma, by $89 \%$ and $47 \%$, respectively. Beatty and Shimshack (2014) found that a $10 \%$ increase in carbon monoxide or ground-level ozone significantly increased respiratory treatments in children by $2-3 \%$, but notably did not find that $\mathrm{PM}_{10}$ significantly increased respiratory treatments. This ambiguity of results in the literature regarding the causal link between $\mathrm{PM}_{10}$ and respiratory health outcomes is also highlighted in the EPA's annual Integrated Science Assessment for Particulate Matter reports.

\section{Data}

To assess the impact of local pollutants on health impacts in Louisiana, I compile a comprehensive data set of pollution and health outcomes. To my knowledge, although other studies have attempted to evaluate the effect of local pollution on health outcomes in the Industrial Corridor, this is the first to use an instrumental variables approach to address and mitigate confounding factors that can bias results. All data sources used in this analysis are publicly available, and are listed in the Data Availability Section 9.

The primary health outcomes considered in this analysis are annual hospitalizations due to asthma at the parish level for the state of Louisiana. Health outcomes data are provided by the Louisiana Department of Health and are available from 2000 - 2015.

I obtain annual, parish-level pollution concentration data from concentration estimates developed by the Center for Air, Climate and Energy Solutions using v1 empirical models as described in Kim et al. (2020). The concentration estimates are derived from publicly available data from the U.S. Environmental Protection Agency (EPA) pollution monitors, land-use information ${ }_{6}^{6}$ and satellite-derived pollution estimates to predict concentrations at locations without air pollution monitors. Pollution concentrations are annual estimates, with the exception of ozone, which is calculated as the average concentration from May through September.

\footnotetext{
(2020).

${ }^{6}$ Land use information includes locations of major and minor roads, elevation, and if an area is rural or urban Kim et al.
} 
I use two primary instruments for pollution, annual barge traffic and annual natural gas prices. Annual barge calls are hand collected from the Port of South Louisiana in its publicly available fourth quarter tonnage statistics reports, available from 1999 - 2020. Citygate natural gas prices are available at the state level from the U.S. Energy Information Administration. I also create a variable to measure the proximity to the Port of South Louisiana using parish-level centroids calculated from a county level spatial map provided by the U.S. Department of Homeland Security's Homeland Infrastructure Foundation-Level Database (HIFLD), and the coordinates to the headquarters of the Port of South Louisiana in LaSalle, Louisiana. I interact a parish's proximity to the port with natural gas prices and barge calls to allow differential pollution effects based on a parish's proximity to the port.

Control variables include weather, GDP, and an annual time trend. Weather variables, including maximum temperature, minimum temperature, and precipitation are collected from the National Oceanic and Atmospheric Agency (NOAA) Global Historical Climatology Network Daily (GHCND) database. The GHCND database provides daily climate normals from various weather stations across the United States. I first identify the five closest weather stations with greater than $80 \%$ data coverage to the parish centroid for each Louisiana parish. I obtain daily weather readings for each weather station from NOAA, replace any missing daily weather readings with those from the next closest station, and calculate annual average readings from the daily readings. GDP is the Gross Domestic Product, Billions of Dollars, Annual, Not Seasonally Adjusted from the Federal Reserve Economic Data (FRED).

Table 2 contains summary statistics for the main variables in my analysis. Means and standard deviations at the parish level are provided for annual hospitalizations for asthma; annual particulate matter $\left(\mathrm{PM}_{10}\right)$ pollution concentration; annual natural gas prices from Citygate and annual barge calls to the Port of South Louisiana; and annual GDP and weather variables. The full sample consists of 1024 observations for each pollutant in a strongly balanced panel.

Table 2: Summary Statistics

\begin{tabular}{|c|c|}
\hline \multicolumn{2}{|l|}{ Health Outcomes } \\
\hline Annual Hospitalizations for Asthma & $\begin{array}{c}95.59 \\
(135.2)\end{array}$ \\
\hline \multicolumn{2}{|l|}{ Pollutant } \\
\hline $\mathrm{PM}_{10}$ Concentration $\left(\mu \mathrm{g} / \mathrm{m}^{3}\right)$ & $\begin{array}{l}19.094 \\
(4.491)\end{array}$ \\
\hline \multicolumn{2}{|l|}{ Instruments } \\
\hline Annual Natural Gas Price (Citygate, in dollars) & $\begin{array}{c}5.824 \\
(1.725)\end{array}$ \\
\hline Port of S. LA Barge Calls & $\begin{array}{r}54374.8 \\
(3909.6)\end{array}$ \\
\hline \multicolumn{2}{|l|}{ Controls } \\
\hline National GDP (Billion \$) & $\begin{array}{l}13998.3 \\
(2386.2)\end{array}$ \\
\hline Precipitation (Inches) & $\begin{array}{c}40.14 \\
(11.49)\end{array}$ \\
\hline Minimum Temperature (Tenths of Degrees Celsius) & $\begin{array}{c}137.5 \\
(19.72)\end{array}$ \\
\hline Maximum Temperature (Tenths of Degrees Celsius) & $\begin{array}{c}251.6 \\
(13.77)\end{array}$ \\
\hline
\end{tabular}




\section{Empirical Framework}

My identification strategy is to use two-stage least squares to estimate the following equations:

$$
\begin{gathered}
h_{i t}=\beta p_{i t}+\mathbf{X} \gamma+\alpha_{i}+\phi_{t}+f(t)+\epsilon_{i t} \\
p_{\text {it }=\delta_{1} \text { barges }_{t}+\delta_{2} \text { barges }_{t} * \text { distance }_{i}+\delta_{3} \text { gasprice }_{t}+\delta_{4} \text { gasprice }_{t} * \text { distance }_{i}}^{+\mathbf{X} \gamma+\alpha_{i}+\phi_{t}+f(t)+\nu_{i t}}
\end{gathered}
$$

where Equation (1) is the second-stage regression and Equation (2) is the first-stage regression. My dependent variable in the second-stage regression, $h_{i t}$, is hospitalizations for asthma in parish, $i$, and year, $t$. I assess the strength of my instruments to a variety of potential confounding variables in vector $\mathbf{X}$. Vector $\mathbf{X}$ includes controls for GDP and weather, and $f(t)$ is an annual time trend. I use GDP to control for annual shocks to economic activity, which could influence natural gas production, barge traffic and health outcomes. I use maximum and minimum temperatures, as well as their squares to flexibly control for seasonal temperatures that can both affect natural gas demand and seasonal respiratory health outcomes, such as cold or flu viruses. I also use a linear time trend to control for long-run trends such as industrial development that could affect natural gas demand, barge traffic and health outcomes. I also include parish-level fixed effects, $\alpha_{i}$, allowing me to identify my results off of within-parish variation in pollution exposure, and control for other persistent differences in parish-level income and demographics that could bias results. In some specifications, when I don't include GDP, I include year fixed effects to control for annual shocks to economic activity and health that could occur through both economic and noneconomic channels, such as changes to air pollution regulations.

I instrument pollution concentration in Equation 1 using barge traffic, barges $s_{t}$, which is annual barge calls to the Port of South Louisiana, and natural gas prices, gasprice ${ }_{t}$, which are state-level Citygate natural gas prices. I interact both barge traffic and natural gas prices with distance, distance $_{i}$, which is a measure of the distance from the headquarters of the Port in LaPlace, St. John the Baptist Parish, Louisiana to the centroid of each respective Louisiana parish. I multiply the distance from the port by negative one, so that a marginal reduction in distance to the port is interpreted as an increase in proximity to the port. Because barge traffic data is only available annually, and tied to industrial output, I cannot rule out the potential for autocorrelation in the error terms. To address this concern, I cluster my errors at the parishlevel.

\section{Local Pollution Instrument}

\subsection{Rationale}

Several features make natural gas prices an appealing instrument. Natural gas is a fossil fuel, and combusting it for energy produces harmful emissions, though generally in reduced quantities compared to oil 
or coal. Table 3 compares the pounds of air pollutants produced per billion British thermal units (Btu) of energy between natural gas, coal, and oil. Natural gas produces significantly less carbon monoxide, nitrogen oxides, sulfur dioxide, and particulates than coal, as well as significantly less nitrogen oxides, sulfur dioxide and particulates than oil. As such, substitution of natural gas for other fossil fuels can substantially reduce local pollution levels.

Table 3: Pounds of Air Pollutants Produced per Billion Btu of Energy

\begin{tabular}{lccc}
\hline \hline & $(1)$ & $(2)$ & $(3)$ \\
Pollutant & & & \\
\hline Carbon Monoxide & 40 & 33 & 208 \\
Nitrogen Oxides & 92 & 448 & 457 \\
Sulfur Dioxide & 0.6 & 1,122 & 2,591 \\
Particulates & 7.0 & 84 & 2,744 \\
\hline \hline & Notes: This table reproduces a selection of emissions from \\
fossil fuels as reported by the Energy Information Adminis- \\
tration (EIA) Natural Gas 1998: Issues and Trends, at page \\
58.
\end{tabular}

In this study, I leverage the arguably exogenous shock to natural gas production from unconventional natural gas development, as measured by changes in natural gas prices, as an instrument for identifying the shift in pollution that potentially occurred due to a shift from other fossil fuels to natural gas. The intuition behind the instrument is that declines in natural gas prices led more industries to shift to natural gas instead of other fossil fuels, resulting in less local air pollution. Figure 1 depicts average annual parish-level $\mathrm{PM}_{10}$ concentration and annual natural gas prices. It's clear that $\mathrm{PM}_{10}$ pollution closely follows natural gas prices, increasing when natural gas prices increase, and decreasing when they decrease in the post-2008, unconventional natural gas development era.

As shown in Table 4 , the intuition behind this instrument is also found in the reduced form regression results. An increase (decrease) in the natural gas price positively (negatively) and significantly increases parish-level particulate matter $\left(\mathrm{PM}_{10}\right)$ pollution concentration. Further corroborating the rationale for the instrument is evidence that as natural gas became cheaper due to unconventional natural gas development, many industries switched from other fossil fuels to natural gas. As shown in Figure 2 natural gas consumption and natural gas derived liquids (hydrocarbon gas liquids) consumption increased post-2008, while consumption of other major fossil fuels declined in Louisiana, likely leading to reduced particulate matter and other local pollutants. These shifts in pollution from natural gas prices likely affect respiratory health outcomes in Louisiana as reduced local pollution has been shown in the literature to improve respiratory health outcomes 7

The Industrial Corridor is a manufacturing zone populated by refineries and chemical processing facilities along the Mississippi River from Baton Rouge to New Orleans, encompassing the parishes of Ascension, East Baton Rouge, Jefferson, Iberville, Orleans, Plaquemines, St. Bernard, St. Charles, St. James,

7 https://ww2.arb.ca.gov/resources/asthma-and-air-pollution 
Figure 1: Parish-Level $\mathrm{PM}_{10}$ Concentration and Natural Gas Prices

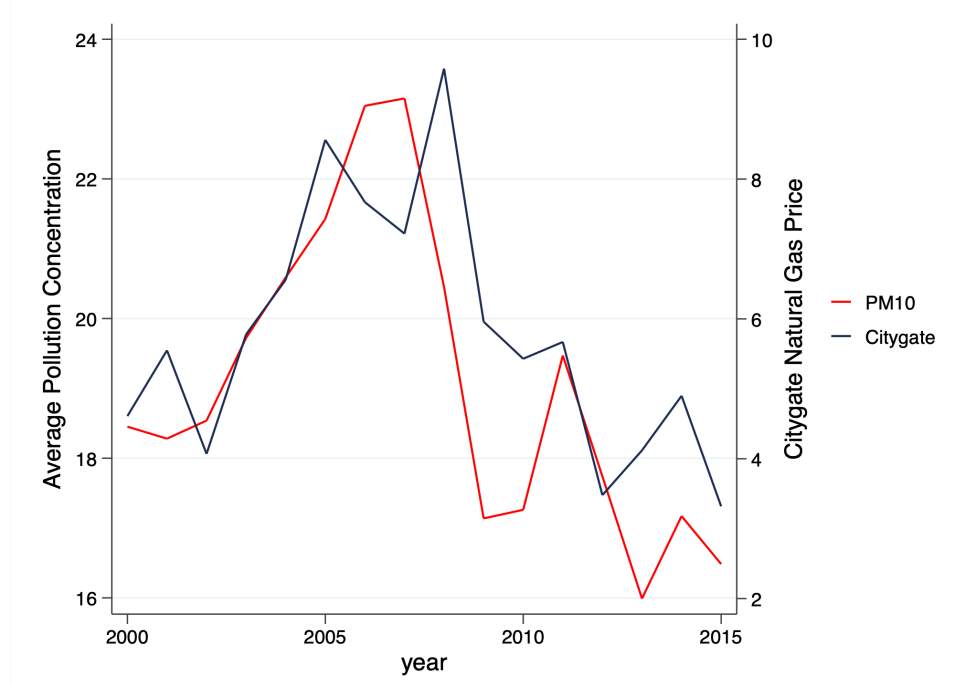

Notes: This figure shows average parish-level $\mathrm{PM}_{10}$ concentration and natural gas prices by year.

St. John the Baptist, and West Baton Rouge 8 The Port of South Louisiana occupies 54 miles of the Industrial Corridor in St. James, St. John the Baptist, and St. Charles Parish, and is the largest tonnage port district in the western hemisphere. Several features make river barge traffic an appealing instrument. First, barge traffic represents a significant portion of Louisiana's industrial activity. In 2015, over half of total throughput at the port was from crude oil, petrochemicals, and chemicals/fertilizers, carried on 57,134 barges and 4413 ocean vessels.9 ${ }^{9}$ Increased barge traffic due to increased imports and exports is arguably a correlated with manufacturing at these industrial facilities, which has pollution implications. As shown in Table 4, the intuition behind this instrument is also found in the reduced form regression results, in which an increase barge traffic positively and significantly increases parish-level particulate matter $\left(\mathrm{PM}_{10}\right)$ pollution concentration. However, the correlation between average, parish-level $\mathrm{PM}_{10}$ pollution concentration and barge calls appears to be more closely related in the post-2008 timeframe, as shown in Figure 3 The large spike in $\mathrm{PM}_{10}$ pollution observed in the pre-2008 timeframe is likely due to another factor - natural gas prices - the post-2008 decline of which arguably led to less emissions-intensive industrial activity in South Louisiana.

Because manufacturing activity in the Industrial Corridor is particularly dense in South Louisiana, I expect that proximity to the port will increase pollution levels, with the highest levels of pollution occurring in those parishes closest to the port. As shown in Figure 4, pollution does generally increase in the Industrial Corridor, from East Baton Rouge through St. Charles Parish, as well as in Southern Louisiana. To allow for differential effects of proximity to the port, I interact both natural gas prices and barge calls

\footnotetext{
$\sqrt[8]{\text { https://ldh.la.gov/assets/oph/Center-EH/envepi/LaTSIP/Documents/Other/HSEES-Miss_Ind_FS.pdf }}$ (accessed

ghttp://portsl.com/wp-content/uploads/2016/03/2015_FourthQ_PSL_Ton_Stats.pdf at p.3 (accessed 9/4/2020).
} 9/4/2020). 
Figure 2: Louisiana Total Consumption of Major Fossil Fuels (in Billion

Btu)

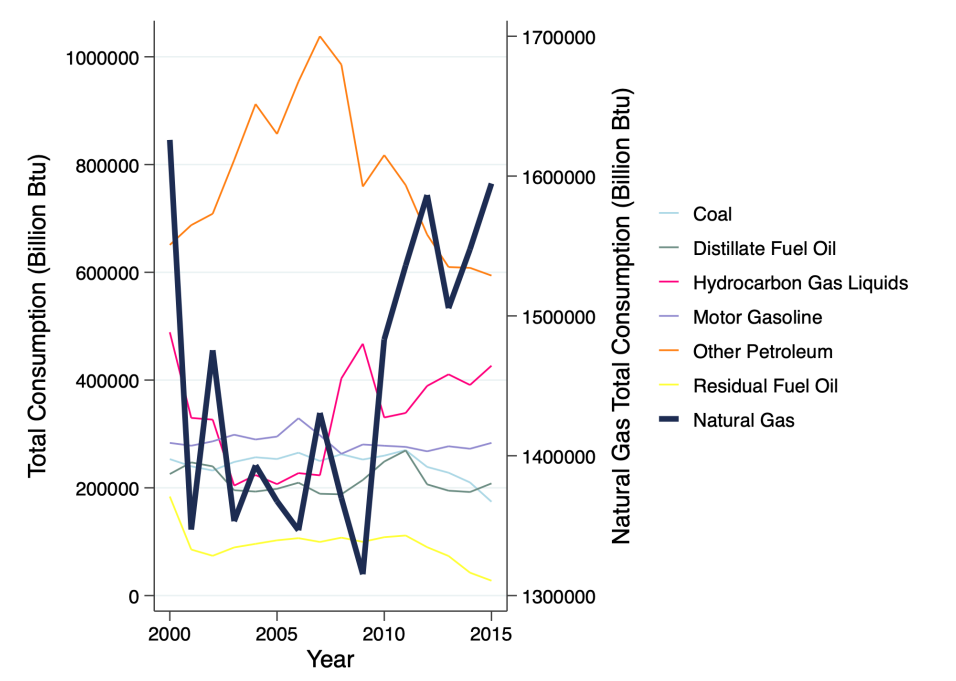

Notes: This figure shows the total consumption of different types of fossil fuels in billion Btus.

Source: EIA State Energy Data System.

with each parish's proximity to the port ${ }^{10}$ The intuition behind these instruments is also confirmed in the first-stage regression results in Table 4 , where an increase in proximity to the port significantly increases parish-level pollution concentration.

\section{Results}

\subsection{Instrument Validity}

To be valid instruments, natural gas prices, barge traffic, and their interactions with the proximity to the Port of South Louisiana should be as good as randomly assigned (conditional on covariates) and have no effect on health outcomes other than through the first-stage (pollution) channel. One concern is that local trends in economic activity, for example, increases in employment opportunities or parish revenues due to natural gas or other industrial activity, can influence both pollution and health outcomes.

To address this concern, I condition my instrumental variables and results on parish-level fixed effects, identifying my results on within parish variation, to control for persistent differences in parish-level income, other demographics, and local economic conditions that could bias outcomes. I account for annual shocks to economic activity — which could influence natural gas production, industrial output, and health

\footnotetext{
${ }^{10}$ As a simplifying step I calculate distance based on the distance from the centroid of the parish to the port headquarters in LaPlace, Louisiana.
} 
Figure 3: Parish-Level $\mathrm{PM}_{10}$ Concentration and Port of South LA Barge Calls

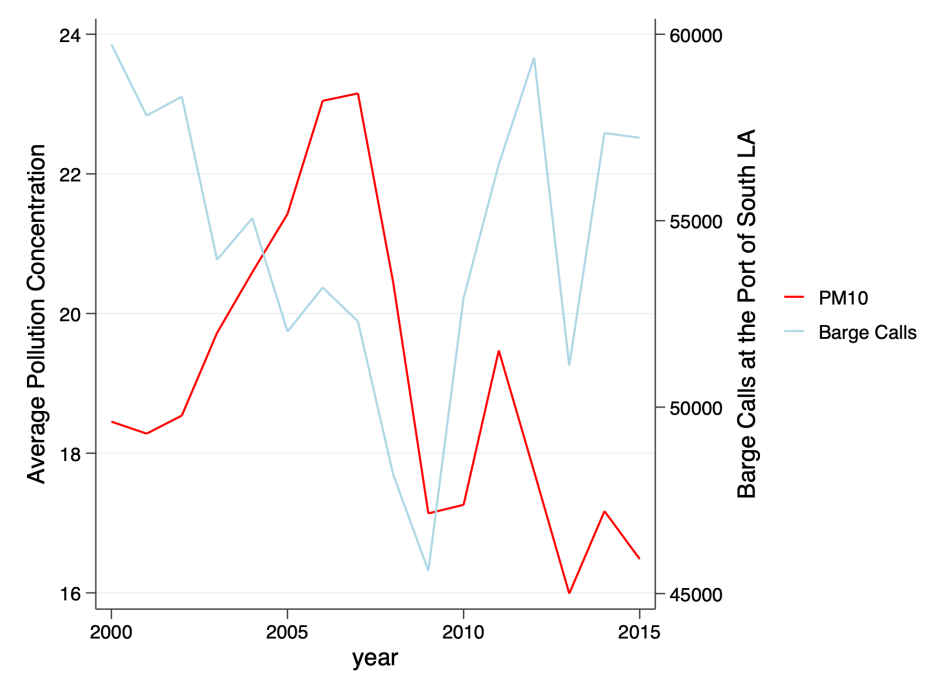

Notes: This figure shows average parish-level $\mathrm{PM}_{10}$ concentration and annual barge calls by year.

outcomes - by controlling for national GDP and annual time trends. In an additional regression specification, I control for the potential for annual shocks to economic activity and health that could occur through non-economic channels, such as changes to air pollution regulations, with year fixed effects and annual time trends. Because weather can also affect natural gas prices via seasonal temperatures which can both influence demand for natural gas and health outcomes, such as cold or flu viruses, I also control for weather variability in some specifications. After conditioning on these controls, I show that results from my instruments are robust to these alternative controls and specifications, corroborating the strength of my instruments, and evidencing that annual variation in natural gas prices and barge traffic is arguably uncorrelated with other short-run determinants of health. More formally, because I have more instruments, $l$, than endogenous variables, $k$, that is $l>k$, I report the result from the Sargan-Hansen test for overidentifying restrictions in Table 4 , where I do not reject the null hypothesis that the instruments are valid instruments, providing evidence that additional instruments are uncorrelated with the error term.

In related literature, instrumenting for shifts in pollution with ocean vessel traffic has been shown to be relevant to and plausibly exogenous from other factors that influence pollution (Moretti and Neidell, 2011). While similar to ocean vessel traffic in the sense that traffic is driven by supply and demand for goods, because the granularity of my data is at the annual level, and barge throughput is closely tied to industrial activity in South Louisiana, I cannot rule out the potential for autocorrelation in the error terms. Because I include parish-level fixed effects in my main specifications, I am primarily concerned with autocorrelation in the time dimension at the parish level. To address this concern, I cluster the errors at the parish level. With 64 parishes and a strongly balanced panel, I have a sufficient number of clusters to remediate this concern. 


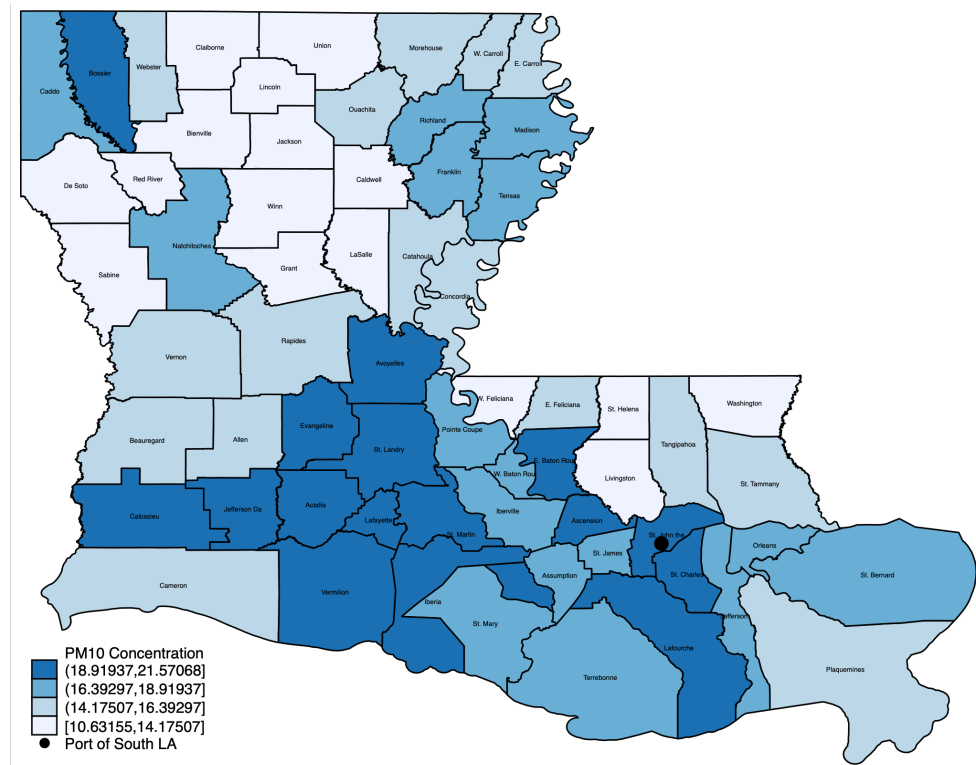

Notes: This figure shows the $2015 \mathrm{PM}_{10}$ pollution concentration by parish in $\mu \mathrm{g} / \mathrm{m}^{3}$.

Source: CACES Pollution Concentration Data.

Although natural gas prices are not typically included as a control variable in the related literature (making natural gas prices a plausibly valid instrument), there is a stream of literature that considers how the proximity of living near oil and natural gas development could adversely affect health outcomes. These studies tend to focus on birth defects or adverse health outcomes at birth, based on a typical measure of exposure such as the number of wells in a county or proximity to wells (Bamber et al. 2019).

In a systematic review of the epidemiological literature on populations living near oil and natural gas operations, Bamber et al. (2019) found that the association between living near oil and natural gas development and respiratory health outcomes is not well understood as other lifestyle factors, such as smoking, can exacerbate pollution's effects on respiratory health outcomes. Further, the epidemiological literature on living near oil and natural gas operations is of inadequate quality and certainty to guide policy on potential health effects. In an earlier review of the literature that spanned from 1995 through 2014, Werner et al. (2015) similarly found that studies on associations between unconventional natural gas development and adverse health outcomes lacked methodological rigor, but did not rule out the possibility of adverse health outcomes. Although the literature is inconclusive, to rule out the potential that natural gas prices are affecting parish-level health outcomes through proximity to oil and natural gas operations, as a robustness test, I include the number of permitted and active wells by parish in the appendix, Table B3. I find that my results are robust to the inclusion of wells, providing some evidence that proximity to oil and gas sites is not a potentially omitted pollution channel in this analysis. 


\subsection{Instrument Relevance}

To provide evidence of the strength of my instruments, in Table 4 , I provide the first-stage regression results. I find that natural gas prices and natural gas prices interacted with proximity to the port are both statistically significant at the $1 \%$ level. My estimates imply that for each $\$ 1$ increase in natural gas prices, $\mathrm{PM}_{10}$ pollution concentration will increase by $1.39 \mu \mathrm{g} / \mathrm{m}^{3}$, or $44 \%$ of the sample average $\mathrm{PM}_{10}$ pollution concentration. To interpret the first-stage results for barge traffic, an increase in annual barge traffic by one standard deviation-roughly 4,000 barges - will increase $\mathrm{PM}_{10}$ pollution concentration by $1.26 \mu \mathrm{g} / \mathrm{m}^{3}$, or $40 \%$ of the sample average $\mathrm{PM}_{10}$ pollution concentration. I expect the impact to $\mathrm{PM}_{10}$ concentration from both natural gas prices and barge calls to increase with a parish's proximity to the port. The positive and significant interaction terms on natural gas prices and barge calls with proximity to the port confirm this relationship.

Both natural gas prices and barge calls significantly impact $\mathrm{PM}_{10}$ pollution levels, and these effects increase with proximity to the Port of South Louisiana, providing evidence of the strength of the first stage results, which are bolstered by large first-stage F statistics. Conditional on control variables, both natural gas prices and barge calls also appear to be uncorrelated with the error term, allowing for consistent estimation of the effect of $\mathrm{PM}_{10}$ pollution concentration on asthma hospitalizations.

Further because I have multiple instruments, I apply several instruments separately from one another, and show that parameters are largely stable. In particular, when IV results are just-identified (with natural gas prices as the single instrument), the effect of PM10 pollution on asthma hospitalizations are only slightly smaller in magnitude than with the full set of instruments. These results are shown in the appendix, Table B4.

Last, because my IV estimates are overidentified, I report the results from my regressions estimated with limited information maximum likelihood (LIML), and show that results estimated with two-stage least squares (2SLS) are robust to LIML. These results are shown in Appendix B.

\subsection{Regression Results}

I present OLS and IV results in Table 4 for the effect of PM10 pollution on asthma hospitalizations. Columns $(1),(3),(5),(7)$ and (9) correspond to OLS results with various control variables, including GDP and an annual trend in Column (3); GDP, an annual trend, and parish-level fixed effects in Column (5); GDP, an annual trend, parish-level fixed effects, and weather control variables in Column (7); and year fixed effects (in lieu of GDP), with all other control variables in Column (9). Columns (2), (4), (6), (8) and (10) correspond to the same control variable specifications for the IV regressions. The IV results presented in Table 4 are estimated with 2SLS, but are robust to LIML estimation as shown in Table B1 in the appendix.

The OLS results in show that PM10 pollution has a positive and significant relationship with asthma hospitalizations. Focusing on Column (7), a one $\mu \mathrm{g} / \mathrm{m}^{3}$ increase in PM10 concentration results in roughly six additional asthma hospitalizations, a $6 \%$ increase in annual average parish-level asthma hospitalizations. However, the OLS results in Column (9) become insignificant with the addition of year fixed effects. As 
particulate matter pollution has been shown in the literature to have a significant effect on health outcomes, this finding suggests that the year fixed effects control for observed and unobserved heterogeneity beyond annual economic shocks accounted for with GDP.

Focusing on the IV results, I find that estimates are roughly twice as large as OLS estimates. A one $\mu \mathrm{g} / \mathrm{m}^{3}$ increase in parish-level PM10 concentration results in 12 additional hospitalizations, or a more than $12 \%$ increase in parish-level asthma hospitalizations. The IV estimates suggest that accounting for unobserved factors that influence both pollution and health outcomes, as well as addressing measurement error in pollution estimates, roughly doubles the estimates. Assessing the sensitivity of the results to other potentially confounding variables that could influence both pollution and health outcomes such as annual shocks to economic activity (GDP), seasonal temperatures that can both affect natural gas demand and seasonal respiratory health outcomes (maximum and minimum temperatures, as well as their squares), persistent differences in parish-level income and demographics (parish-level fixed effects), long-run trends such as industrial development that could affect natural gas demand, barge traffic and health outcomes (linear time trend), as well as annual shocks to economic activity and health that could occur through both economic and non-economic channels, such as changes to air pollution regulations (year fixed effects), I find that estimates are relatively stable, suggesting the instrumental variables appropriately account for confounders. Columns (1) and (2) contain the baseline specification with just the effect of the instrumented PM10 pollution on parish-level asthma hospitalization counts, columns (3) and (4) include GDP and an annual time trend, Columns (5) and (6) include GDP, an annual time trend, and parish-level fixed effects, Columns (7) and (8) add weather variables, and Columns (9) and (10) control for year fixed effects in lieu of GDP.

As the shale revolution's impact on natural gas prices and subsequent manufacturing renaissance in Southern Louisiana could have also impacted respiratory health outcomes by affecting other local pollutant concentrations, it's possible that other pollutants ( $\mathrm{PM} 2.5, \mathrm{CO}, \mathrm{SO}_{2}, \mathrm{NO}_{2}$, and $\mathrm{O}_{3}$ ) could affect asthma hospitalizations (and the exclusion restriction of the instrument). In Table B2 I explicitly control for these pollutants and find that my results are not sensitive to excluding other local pollutants.

\begin{tabular}{|c|c|c|c|c|c|c|c|c|c|c|}
\hline & 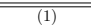 & $\overline{(2)}$ & (3) & (4) & $(5)$ & 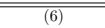 & (7) & (8) & 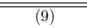 & 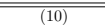 \\
\hline Dependent variable: Asthma & OLS & 2SLS & OLS & 2SLS & OLS & 2SLS & OLS & 2SLS & OLS & 2 SLS \\
\hline Concentration & $\begin{array}{c}7.418621^{* *} \\
(3.136193)\end{array}$ & $\begin{array}{c}9.670626^{*} \\
(5.256508)\end{array}$ & $\begin{array}{l}8.313515^{* *} \\
(3.508258)\end{array}$ & $\begin{array}{l}13.924973^{*} \\
(7.822596)\end{array}$ & $\begin{array}{c}5.730948^{* * * *} \\
(1.353197)\end{array}$ & $\begin{array}{c}9.860997^{* * * *} \\
(2.381317)\end{array}$ & $\begin{array}{c}5.780759^{* * * *} \\
(1.239690)\end{array}$ & $\begin{array}{c}11.390044^{* * * *} \\
(2.59144)\end{array}$ & $\begin{array}{c}5.565285 \\
(3.639024)\end{array}$ & $\begin{array}{c}2.243745^{* * *} \\
(4.428734)\end{array}$ \\
\hline GDP & $\mathrm{N}$ & $\mathrm{N}$ & $\mathrm{Y}$ & $\mathrm{Y}$ & $\mathrm{Y}$ & $\mathrm{Y}$ & $\mathrm{Y}$ & $\mathrm{Y}$ & $\mathrm{N}$ & $\mathrm{N}$ \\
\hline Year FE. & $\mathrm{N}$ & $\mathrm{N}$ & $\mathrm{N}$ & $\mathrm{N}$ & $\mathrm{N}$ & $\mathrm{N}$ & $\mathrm{N}$ & $\mathrm{N}$ & $\mathrm{Y}$ & $\mathrm{Y}$ \\
\hline Annual Trend & $\mathrm{N}$ & $\mathrm{N}$ & $\mathrm{Y}$ & $\mathrm{Y}$ & $\mathrm{Y}$ & $\mathrm{Y}$ & $\mathrm{Y}$ & $\mathrm{Y}$ & $\mathrm{Y}$ & $\mathrm{Y}$ \\
\hline Parish FE & $\mathrm{N}$ & $\mathrm{N}$ & $\mathrm{N}$ & $\mathrm{N}$ & $\mathrm{Y}$ & $\mathrm{Y}$ & $\mathrm{Y}$ & $\mathrm{Y}$ & $\mathrm{Y}$ & $\mathrm{Y}$ \\
\hline Weather & $\mathrm{N}$ & $\mathrm{N}$ & $\mathrm{N}$ & $\mathrm{N}$ & $\mathrm{N}$ & $\mathrm{N}$ & $\mathrm{Y}$ & $\mathrm{Y}$ & $\mathrm{Y}$ & $\mathrm{Y}$ \\
\hline \multicolumn{11}{|c|}{ First Stage Instrument } \\
\hline Citygate & & $\begin{array}{c}1.49118^{* * *} \\
(0.08168)\end{array}$ & & $\begin{array}{c}1.03301 * * * \\
(0.08714)\end{array}$ & & $\begin{array}{c}1.34690^{* * * *} \\
(0.07456)\end{array}$ & & $\begin{array}{c}1.39302^{* * *} * \\
(0.07273)\end{array}$ & & $\begin{array}{c}0.80482^{* * *} \\
(0.14417)\end{array}$ \\
\hline Proximity to Port X Citygate & & $\begin{array}{l}0.00136^{* * *} \\
(0.00032)\end{array}$ & & $\begin{array}{c}0.00135 * * * \\
(0.00032)\end{array}$ & & $\begin{array}{c}0.00275^{* * *} \\
(0.00030)\end{array}$ & & $\begin{array}{c}0.00277^{* * * *} \\
(0.00031)\end{array}$ & & $\begin{array}{c}0.00273^{* * *} \\
(0.00029)\end{array}$ \\
\hline Barge Calls & & $\begin{array}{c}0.000265^{* * * *} \\
(0.000016)\end{array}$ & & $\begin{array}{c}0.000143^{* * * *} \\
(0.000021)\end{array}$ & & $\begin{array}{c}0.000309^{* * * *} \\
(0.000022)\end{array}$ & & $\begin{array}{c}0.000315^{* * * *} \\
(0.000023)\end{array}$ & & $0.000380^{* * *}$ \\
\hline Proximity to Port X Barge Calls & & $0.000000^{* * * *}$ & & $0.000001^{* * * *}$ & & $0.000001^{* * * *}$ & & $0.000001^{* * * *}$ & & (0 000000) \\
\hline Kleibergen-Paap Wald rk F statistic for IV in first stage & & $\begin{array}{c}0.000018 \\
147.726\end{array}$ & & $\begin{array}{c}(0.000000) \\
51.870\end{array}$ & & $\begin{array}{c}(0.000000) \\
130.836\end{array}$ & & $\begin{array}{c}(0.000000) \\
145.904\end{array}$ & & 79.797 \\
\hline P-Value of Anderson-Rubin test & & 0.006 & & 0.012 & & 0.000 & & 0.000 & & 0.009 \\
\hline P-Value of Hansen J statistic & & 0.262 & & 0.251 & & 0.172 & & 0.228 & & 0.199 \\
\hline $\mathrm{N}$ & 970 & 970 & 970 & 970 & 970 & 970 & 970 & 970 & 970 & 970 \\
\hline Mean Dependent Variable & 95.313 & 95.313 & 95.313 & 95.313 & 95.313 & 95.313 & 95.313 & 95.313 & 95.313 & 95.313 \\
\hline Std. Dev. Dependent Variable & 135.103 & 135.103 & 135.103 & 135.103 & 135.103 & 135.103 & 135.103 & 135.103 & 135.103 & 135.103 \\
\hline
\end{tabular}




\subsection{Estimated Benefits}

To estimate the benefits of reducing pollution exposure on health outcomes, I first define health outcomes as a production function that depends on pollution exposure $(p)$ and other defensive measures $(d(p))$ such as air filters or other unobserved behaviors that are taken to avoid pollution, where $h=h(p, d)$ and $\partial h / \partial d<$ $0<\partial h / \partial p$. Taking the total derivative, $h p=\frac{\partial h}{\partial p}+\frac{\partial h}{\partial d} * \frac{\partial d}{\partial p}$, gives the total effect of pollution on health. From this expression, Harrington and Portney (1987) have shown that $\partial h / \partial p$, or the observed cost of illness (COI) for a change in pollution can be expressed as COI $=[m+w] \partial h / \partial p$, where $m$ are the out-ofpocket medical costs and $w$ are the lost wages due to illness from pollution. The observed COI underestimates the willingness to pay (WTP) to reduce pollution exposure by the change in unobserved defensive measures taken to avoid pollution. The OLS estimates, which are equivalent to $\partial h / \partial p$, underestimate the true WTP to avoid pollution. The IV estimates, however, account for defensive measures and other unobserved factors that influence both pollution and health outcomes.

Estimates of the costs of asthma hospitalization vary in the literature. Wang et al. (2014) found that the annual average charge for an asthma-related emergency department outpatient visit was $\$ 1,502$ based on the Medical Expenditure Panel Survey from 2006 - 2008. The Louisiana Department of Health found that the average expenditure for persons with persistent asthma ${ }^{11}$ was between $\$ 1,714-\$ 2,453$, depending on a recipients age 12 Further the CDC found that the annual per-person medical cost of asthma was $\$ 3,266$, of which: $\$ 1830$ was attributed to prescriptions, $\$ 640$ to office visits, $\$ 529$ to hospitalizations, $\$ 176$ to hospital outpatient visits, and $\$ 105$ to emergency room visits. Further, the CDC study found that children with asthma missed 2.3 additional school days annually during 2008 - 2013, while adults with asthma missed 1.8 days annually (Syamlal and K.E. 2020).

Using a benchmark estimate of $\$ 1,500$ per hospitalization and an average of 2 days of missed work, with an average hourly wage of $\$ 21 /$ hour ${ }^{13}$ the OLS estimates (of an increase of 5.5 asthma hospitalizations per parish) imply the benefits of reducing PM10 pollution by one $\mu \mathrm{g} / \mathrm{m}^{3}$ results in a $\$ 8,481$ in benefits per parish, or $\$ 542,784$ for Louisiana's 64 parishes each year. The IV estimates (of an increase of 12.2 asthma hospitalizations per parish) imply the benefits of reducing PM10 pollution by one $\mu \mathrm{g} / \mathrm{m}^{3}$ are $\$ 18,812$ per parish or $\$ 1,203,993$ for Louisiana's 64 parishes each year. These estimates imply that average levels of PM10 exposure $\left(19.1 \mu \mathrm{g} / \mathrm{m}^{3}\right)$ cost Louisianans $\$ 23$ million per year.

\section{Conclusion}

I utilize the shale revolution's impact on industrial development in Louisiana to identify the short-run effects of air pollution on respiratory morbidity (asthma). My empirical approach-instrumenting for PM10

\footnotetext{
${ }^{11}$ Criteria for this designation included at least on emergency room visit, with asthma as the principal diagnosis and/or at least one acute inpatient discharge, with asthma as the principal diagnosis.

12 http://1dh.la.gov/assets/oph/pcrh/asthma/LouisianaAsthmaBurdenReportMarch2010.pdf (accessed 1/18/2021).

${ }^{13}$ Based on May 2019 U.S. Bureau of Labor Statistics for the State of Louisiana. https://www.bls.gov/oes/current/oes_ la.htm (accessed 1/19/2021).
} 
pollution with natural gas prices, barge activity in the Port of South Louisiana, and allowing for the differential effects of a parish's proximity to the port - allows me to identify the causal effect of PM10 pollution on asthma hospitalizations in Louisiana, while controlling for potentially confounding variables that influence pollution exposure and health outcomes.

I find that that increases in natural gas prices and river barge traffic significantly increase parish-level average $\mathrm{PM}_{10}$ pollution concentration, and these effects increased with a parish's proximity to the Port of South Louisiana. My IV estimates, which account for observable and unobservable confounding variables are roughly twice as large as OLS estimates, evidencing the importance of accounting for observable and unobservable behaviors, such as avoidance behaviors and other defensive measures, in estimating the effect of PM10 pollution exposure on health outcomes. The economic impacts of my findings for Louisiana are that a one $\mu \mathrm{g} / \mathrm{m}^{3}$ increase in parish-level PM10 concentration results in 12 additional hospitalizations, or a more than $12 \%$ increase in parish-level asthma hospitalizations, costing Louisianans an additional $\$ 1.2$ million per year, or $\$ 23$ million at average levels of parish-level PM10 exposure. With one in 10 Louisianans suffering from asthma, it is one of the largest health burdens in the state. My research indicates that lowering exposure to PM10 pollution, through fuel-switching to cleaner fuels like natural gas, have a positive benefit.

My findings are relevant to economic policies that address the human health outcomes from industrial development. My findings indicate that switching from other fossil fuels to natural gas as a feedstock generates improvement in pollution and health outcomes, but pollution exposure in densely populated industrial corridors remains an issue. Clean energy technologies that reduce harmful emissions, such as carbon capture utilization and storage (CCUS), energy efficiency, and some forms of industrial demand response remain necessities to improve health outcomes for industrial communities.

\section{Data Availability}

Datasets related to this article can be found at:

Louisiana Department of Health. "Health Data Portal." https://healthdata.ldh.la.gov/.

Center for Air, Climate and Energy Solutions and the Environmental Protection Agency. "Land Use Regression." https://www.caces.us/.

Port of South Louisiana. "Fourth Quarter Tonnage Statistics Reports." http://portsl.com/statistics/.

U.S. Energy Information Administration. "Natural Gas Prices: City Gate Price." https://www.eia.gov/ dnav/ng/ng_pri_sum_a_epg0_pg1_dmcf_m.htm

U.S. Energy Information Administration. "State Energy Data System: All Consumption Estimates in Btu." https://www.eia.gov/state/seds/seds-data-complete.php?sid=US\#Consumption.

Department of Homeland Security. "Homeland Infrastructure Foundation-Level Data." https://hifld-gepplatform. opendata.arcgis.com/.

National Oceanic and Atmospheric Agency. "Global Historical Climatology Network Daily (GHCND)

Database." https://www.ncdc.noaa.gov/data-access/land-based-station-data/land-based-datasets/ 
global-historical-climatology-network-ghcn

Federal Reserve Economic Data. "Gross Domestic Product, Billions of Dollars, Annual, Not Seasonally Adjusted." https://fred.stlouisfed.org/series/GDPA.

Louisiana Department of Natural Resources. "SONRIS Data Portal. Wells by Parish." http://www.dnr . louisiana.gov/index.cfm/iframe/340

\section{References}

Bamber, A. M., Hasanali, S. H., Nair, A. S., Watkins, S. M., Vigil, D. I., Van Dyke, M., McMullin, T. S. and Richardson, K. (2019). A systematic review of the epidemiologic literature assessing health outcomes in populations living near oil and natural gas operations: study quality and future recommendations, International journal of environmental research and public health 16(12): 2123.

Beatty, T. K. and Shimshack, J. P. (2014). Air pollution and children's respiratory health: A cohort analysis, Journal of Environmental Economics and Management 67(1): 39-57.

Chay, K. Y. and Greenstone, M. (2003). The impact of air pollution on infant mortality: evidence from geographic variation in pollution shocks induced by a recession, The quarterly journal of economics 118(3): 1121-1167.

Clancy, L., Goodman, P., Sinclair, H. and Dockery, D. W. (2002). Effect of air-pollution control on death rates in dublin, ireland: an intervention study, The lancet 360(9341): 1210-1214.

Deschenes, O., Greenstone, M. and Shapiro, J. S. (2017). Defensive investments and the demand for air quality: Evidence from the nox budget program, American Economic Review 107(10): 2958-89.

Dockery, D. W. and Pope, C. A. (1994). Acute respiratory effects of particulate air pollution, Annual review of public health 15(1): 107-132.

Dockery, D. W., Pope, C. A., Xu, X., Spengler, J. D., Ware, J. H., Fay, M. E., Ferris Jr, B. G. and Speizer, F. E. (1993). An association between air pollution and mortality in six us cities, New England journal of medicine 329(24): 1753-1759.

Gallagher, P., Lazarus, W., Shapouri, H., Conway, R., Bachewe, F. and Fischer, A. (2010). Cardiovascular disease - risk benefits of clean fuel technology and policy: a statistical analysis, Energy Policy 38(2): 1210-1222.

Gauderman, W. J., Vora, H., McConnell, R., Berhane, K., Gilliland, F., Thomas, D., Lurmann, F., Avol, E., Kunzli, N., Jerrett, M. et al. (2007). Effect of exposure to traffic on lung development from 10 to 18 years of age: a cohort study, The Lancet 369(9561): 571-577.

Greenstone, M. and Hanna, R. (2014). Environmental regulations, air and water pollution, and infant mortality in india, American Economic Review 104(10): 3038-72.

Guarnieri, M. and Balmes, J. R. (2014). Outdoor air pollution and asthma, The Lancet 383(9928): 15811592. 
Harrington, W. and Portney, P. R. (1987). Valuing the benefits of health and safety regulation, Journal of Urban Economics 22(1): 101-112.

Holland, W., Bennett, A., Cameron, I., Florey, C. d. V., Leeder, S., Schilling, R., Swan, A. and Waller, R. (1979). Health effects of particulate pollution: reappraising the evidence, American Journal of Epidemiology 110(5): 527-527.

Janke, K., Propper, C. and Henderson, J. (2009). Do current levels of air pollution kill? the impact of air pollution on population mortality in england, Health economics 18(9): 1031-1055.

Jerrett, M., Burnett, R. T., Pope III, C. A., Ito, K., Thurston, G., Krewski, D., Shi, Y., Calle, E. and Thun, M. (2009). Long-term ozone exposure and mortality, New England Journal of Medicine 360(11): 1085-1095.

Kim, S.-Y., Bechle, M., Hankey, S., Sheppard, L., Szpiro, A. A. and Marshall, J. D. (2020). Concentrations of criteria pollutants in the contiguous us, 1979-2015: Role of prediction model parsimony in integrated empirical geographic regression, PloS one 15(2): e0228535.

Knittel, C. R., Miller, D. L. and Sanders, N. J. (2016). Caution, drivers! children present: Traffic, pollution, and infant health, Review of Economics and Statistics 98(2): 350-366.

Lleras-Muney, A. (2010). The needs of the army using compulsory relocation in the military to estimate the effect of air pollutants on children's health, Journal of Human Resources 45(3): 549-590.

Moretti, E. and Neidell, M. (2011). Pollution, health, and avoidance behavior evidence from the ports of los angeles, Journal of human Resources 46(1): 154-175.

Neidell, M. (2009). Information, avoidance behavior, and health the effect of ozone on asthma hospitalizations, Journal of Human resources 44(2): 450-478.

Neidell, M. (2010). Air quality warnings and outdoor activities: evidence from southern california using a regression discontinuity design, Journal of Epidemiology $\&$ Community Health 64(10): 921-926.

Neidell, M. J. (2004). Air pollution, health, and socio-economic status: the effect of outdoor air quality on childhood asthma, Journal of health economics 23(6): 1209-1236.

Peters, A. (2005). Particulate matter and heart disease: evidence from epidemiological studies, Toxicology and applied pharmacology 207(2): 477-482.

Pope, C. A. (1989). Respiratory disease associated with community air pollution and a steel mill, utah valley., American journal of public health 79(5): 623-628.

Pope, C. A., Burnett, R. T., Thun, M. J., Calle, E. E., Krewski, D., Ito, K. and Thurston, G. D. (2002). Lung cancer, cardiopulmonary mortality, and long-term exposure to fine particulate air pollution, Jama 287(9): 1132-1141.

Pope, C. A., Dockery, D. W. and Schwartz, J. (1995). Review of epidemiological evidence of health effects of particulate air pollution, Inhalation toxicology 7(1): 1-18. 
Pope, C. A., Thun, M. J., Namboodiri, M. M., Dockery, D. W., Evans, J. S., Speizer, F. E. and Heath, C. W. (1995). Particulate air pollution as a predictor of mortality in a prospective study of us adults, American journal of respiratory and critical care medicine 151(3): 669-674.

Ross, M. A. (2009). Integrated science assessment for particulate matter, US Environmental Protection Agency: Washington DC, USA pp. 61-161.

Sheffield, P., Roy, A., Wong, K. and Trasande, L. (2011). Fine particulate matter pollution linked to respiratory illness in infants and increased hospital costs, Health Affairs 30(5): 871-878.

Syamlal, G., B. A. and K.E., D. (2020). Medical expenditures attributed to asthma and chronic obstructive pulmonary disease among workers - united states, 2011 - 2015., MMMR Morb Mortal Wkly Rep 69: $809-814$.

Wang, Tiffany adn Srebotnjak, T., Brownell, J. and Hsia, R. Y. (2014). Emergency department charges for asthma-related outpatient visits by insurance status, Journal of Healthcare for the Poor and Underserved 25(1): 396 .

Wang, X., Ding, H., Ryan, L. and Xu, X. (1997). Association between air pollution and low birth weight: a community-based study., Environmental health perspectives 105(5): 514-520.

Werner, A. K., Vink, S., Watt, K. and Jagals, P. (2015). Environmental health impacts of unconventional natural gas development: a review of the current strength of evidence, Science of the Total Environment 505: $1127-1141$.

Wilson, R., Spengler, J. D. et al. (1996). Particles in our air: concentrations and health effects, Harvard School of Public Health Cambridge, MA. 
Appendix A Map of the Port of South Louisiana 







\section{Appendix B Sensitivity Analysis of Results to Alternative Specifications and Pollutants}

\section{B.1 Robustness of Results to Limited Information Maximum Likelihood}

I present OLS and IV results in Table B1 for the effect of PM10 pollution on asthma hospitalizations, estimated with limited information maximum likelihood (LIML). Columns (1), (3), (5), (7) and (9) correspond to OLS results with various control variables, including GDP and an annual trend in Column (3); GDP, an annual trend, and parish-level fixed effects in Column (5); GDP, an annual trend, parish-level fixed effects, and weather control variables in Column (7); and year fixed effects (in lieu of GDP), with all other control variables in Column (9). Columns (2), (4), (6), (8) and (10) correspond to the same control variable specifications for the IV regressions. The IV results presented in Table B1 are largely the same as those estimated with 2SLS, providing evidence that the results are not biased.

\begin{tabular}{|c|c|c|c|c|c|c|c|c|c|c|}
\hline & (1) & (2) & (3) & (4) & (5) & (6) & (7) & (8) & (9) & (10) \\
\hline Dependent variable: Asthma & OLS & LIML & OLS & LIML & OLS & LIML & OLS & LIML & & \\
\hline Concentration & $\begin{array}{l}7.42^{* *} \\
(3.14)\end{array}$ & $\begin{array}{l}9.77^{*} \\
(5.42)\end{array}$ & $\begin{array}{l}8.313515^{* *} \\
(3.508258)\end{array}$ & $\begin{array}{c}13.991327^{*} \\
(7.894386)\end{array}$ & $\begin{array}{c}5.730948^{* * *} \\
(1.353197)\end{array}$ & $\begin{array}{c}9.938371^{* * *} \\
(2.415145)\end{array}$ & $\begin{array}{c}5.780759^{* * * *} \\
(1.239690)\end{array}$ & $\begin{array}{c}11.469092^{* * *} \\
(2.618838)\end{array}$ & $\begin{array}{c}5.565285 \\
(3.639024)\end{array}$ & $\begin{array}{c}12.561292 * * * \\
(4.605990)\end{array}$ \\
\hline GDP & $\mathrm{N}$ & $\mathrm{N}$ & $\mathrm{Y}$ & $\mathrm{Y}$ & $\mathrm{Y}$ & $\mathrm{Y}$ & $\mathrm{Y}$ & $\mathrm{Y}$ & $\mathrm{N}$ & $\mathrm{N}$ \\
\hline Year FE. & $\mathrm{N}$ & $\mathrm{N}$ & $\mathrm{N}$ & $\mathrm{N}$ & $\mathrm{N}$ & $\mathrm{N}$ & $\mathrm{N}$ & $\mathrm{N}$ & $\mathrm{Y}$ & $\mathrm{Y}$ \\
\hline Annual Trend & $\mathrm{N}$ & $\mathrm{N}$ & $\mathrm{Y}$ & $\mathrm{Y}$ & $\mathrm{Y}$ & $\mathrm{Y}$ & $\mathrm{Y}$ & $\mathrm{Y}$ & $\mathrm{Y}$ & $\mathrm{Y}$ \\
\hline Parish FE & $\mathrm{N}$ & $\mathrm{N}$ & $\mathrm{N}$ & $\mathrm{N}$ & $\mathrm{Y}$ & $\mathrm{Y}$ & $\mathrm{Y}$ & $\mathrm{Y}$ & $\mathrm{Y}$ & $\mathrm{Y}$ \\
\hline Weather & $\mathrm{N}$ & $\mathrm{N}$ & $\mathrm{N}$ & $\mathrm{N}$ & $\mathrm{N}$ & $\mathrm{N}$ & $\mathrm{Y}$ & $\mathrm{Y}$ & $\mathrm{Y}$ & $\mathrm{Y}$ \\
\hline \multicolumn{11}{|c|}{ First Stage Instrument } \\
\hline Citygate & & $\begin{array}{c}1.49118^{* * *} \\
(0.08168)\end{array}$ & & $\begin{array}{c}1.03301^{* * *} \\
(0.08714)\end{array}$ & & $\begin{array}{c}1.34690^{* * *} \\
(0.07456)\end{array}$ & & $\begin{array}{c}1.39302 * * * \\
(0.07273)\end{array}$ & & $\begin{array}{c}0.80482^{* * *} \\
(0.14417)\end{array}$ \\
\hline Proximity to Port X Citygate & & $\begin{array}{c}0.00136^{* * * *} \\
(0.00032)\end{array}$ & & $\begin{array}{c}0.00135^{* * *} \\
(0.00030)\end{array}$ & & $\begin{array}{c}0.00275^{* * * *} \\
(0.00031)\end{array}$ & & $\begin{array}{c}0.00277^{* * *} \\
(0.00029)\end{array}$ & & $0.00273^{* * *}$ \\
\hline Barge Calls & & $\begin{array}{c}0.000265^{* * *} \\
0.000018\end{array}$ & & $\begin{array}{c}0.000143^{* * *} \\
(0.000016)\end{array}$ & & $\begin{array}{c}0.000309^{* * *} \\
(0.000021)\end{array}$ & & $\begin{array}{c}0.000315^{* * *} \\
(0.000022)\end{array}$ & & $\begin{array}{c}0.000380^{* * *} \\
0.000023\end{array}$ \\
\hline Proximity to Port X Barge Calls & & $\begin{array}{c}0.000000 \text { **** } \\
(0.000000)\end{array}$ & & $\begin{array}{c}0.000000^{* * * *} \\
(0.000000)\end{array}$ & & $\begin{array}{c}0.000001^{* * * *} \\
(0.000000)\end{array}$ & & $\begin{array}{c}0.000001^{* * *} \\
(0.000000)\end{array}$ & & $0.000001^{* * *}$ \\
\hline Kleibergen-Paap Wald rk F statistic for IV in first stage & & 147.726 & & 51.870 & & 130.836 & & 145.904 & & 79.797 \\
\hline P-Value of Anderson-Rubin test & & 0.006 & & 0.012 & & 0.000 & & 0.000 & & 0.009 \\
\hline P-Value of Hansen J statistic & & 0.262 & & 0.252 & & 0.173 & & 0.229 & & 0.199 \\
\hline $\mathrm{N}$ & 970 & 970 & 970 & 970 & 970 & 970 & 970 & 970 & 970 & 970 \\
\hline Mean Dependent Variable 95.313 & 95.313 & 95.313 & 95.313 & 95.313 & 95.313 & 95.313 & 95.313 & 95.313 & 95.313 & \\
\hline Std. Dev. Dependent Variable & 135.103 & 135.103 & 135.103 & 135.103 & 135.103 & 135.103 & 135.103 & 135.103 & 135.103 & 135.103 \\
\hline
\end{tabular}

\section{B.2 Robustness of Results to Copollutants}

I present OLS and IV results in Table B2 for the effect of PM10 pollution on asthma hospitalizations, estimated with copollutants $\left(\mathrm{CO}, \mathrm{NO}_{2}, \mathrm{O}_{3}, \mathrm{PM} 2.5\right.$, and $\left.\mathrm{SO}_{2}\right)$. Column (1) corresponds to OLS results with various control variables, including year fixed effects, an annual trend, parish-level fixed effects, weather control variables and copollutant controls. Column (2) corresponds to the same control variable specifications for the IV regression. The IV results presented in Table B2 are largely the same as those estimates without excluding other local pollutants (Table 4, column (10)), providing evidence that the effect of PM10 pollution on asthma hospitalizations is not driven by other local pollutant concentrations. 
Table B2: Robustness of Results to Copollutants

\begin{tabular}{lcc}
\hline \hline & $(1)$ & $(2)$ \\
Dependent variable: Asthma & OLS & 2SLS \\
\hline & & \\
\hline Concentration & 3.67 & $12.68^{* * *}$ \\
Year FE. & $(2.85)$ & $(4.43)$ \\
Annual Trend & $\mathrm{Y}$ & $\mathrm{Y}$ \\
Parish FE & $\mathrm{Y}$ & $\mathrm{Y}$ \\
Weather & $\mathrm{Y}$ & $\mathrm{Y}$ \\
Controls for Copollutants & $\mathrm{Y}$ & $\mathrm{Y}$ \\
\hline
\end{tabular}

First Stage Instrument

\begin{tabular}{lc} 
Citygate & $0.64116^{* * *}$ \\
Proximity to Port X Citygate & 0.14826 \\
& $0.00263^{* * *}$ \\
Barge Calls & 0.00026 \\
& $0.000303^{* * *}$ \\
Proximity to Port X Barge Calls & 0.000025 \\
& $0.000001^{* * *}$ \\
Kleibergen-Paap Wald rk F statistic for IV in first stage & 0.000000 \\
P-Value of Anderson-Rubin test & 53.600 \\
P-Value of Hansen J statistic & 0.010 \\
N & 0.296 \\
Mean Dependent Variable & 970 \\
Std. Dev. Dependent Variable & 970 \\
\hline \hline
\end{tabular}

Notes: The coefficient estimates reported in Column (1) are the OLS results with year fixed effects, an annual trend, parish-level fixed effects, weather control variables, and local pollution concentrations for $\mathrm{CO}, \mathrm{NO}_{2}, \mathrm{O}_{3}, \mathrm{PM} 2.5$, and $\mathrm{SO}_{2}$. Column (2) reports the 2SLS results for the same specification. First-stage results are reported in the bottom panel of the table, along with the KleibergenPaap Wald Statistic, the p-value for the Anderson-Rubin test, and the p-value for the Hansen J statistic. Errors are clustered at the parish-level. ${ }^{*} \mathrm{p}<0.10,{ }^{* *} \mathrm{p}<0.05,{ }^{* * *} \mathrm{p}<0.01$.

\section{B.3 Robustness of Results to Inclusion of Oil and Gas Wells}

I present OLS and IV results in Table B3 for the effect of PM10 pollution on asthma hospitalizations, estimated with permitted, new, and active wells by parish. Column (1) corresponds to OLS results with various control variables, including year fixed effects, an annual trend, parish-level fixed effects, weather control variables and well controls. Column (2) corresponds to the same control variable specifications for the IV regression. The IV results presented in Table B2 are largely the same as those estimates without excluding other local pollutants (Table 4, column (10)), providing evidence that the effect of PM10 pollution on asthma hospitalizations is not driven by other factors (wells) affecting local air pollution. 
Table B3: Effects of Asthma from PM10 Concentration - Robust to Oil and Gas Wells

\begin{tabular}{lcc}
\hline \hline & $(1)$ & $(2)$ \\
Dependent variable: Asthma & OLS & 2SLS \\
\hline & & \\
\hline Concentration & $4.080515^{* *}$ & $13.069343^{* *}$ \\
Permitted Wells & $(1.896260)$ & $(5.323234)$ \\
& -0.220715 & -0.195267 \\
New Wells & $(0.297959)$ & $(0.277086)$ \\
& 0.231141 & 0.177228 \\
Active Wells & $(0.221053)$ & $(0.209625)$ \\
& 0.298908 & 0.276298 \\
GDP & $(0.251044)$ & $(0.226348)$ \\
Annual Trend & $\mathrm{Y}$ & $\mathrm{Y}$ \\
Parish FE & $\mathrm{Y}$ & $\mathrm{Y}$ \\
Weather & $\mathrm{Y}$ & $\mathrm{Y}$ \\
\hline
\end{tabular}

First Stage Instrument

\begin{tabular}{|c|c|c|}
\hline Citygate & & $\begin{array}{c}1.46531^{* * *} \\
0.14866\end{array}$ \\
\hline Proximity to Port X Citygate & & $\begin{array}{c}0.00290^{* * *} \\
0.00049\end{array}$ \\
\hline Barge Calls & & $\begin{array}{c}0.000332^{* * *} \\
0.000057\end{array}$ \\
\hline Proximity to Port X Barge Calls & & $\begin{array}{c}0.000001^{* * *} \\
0.000000\end{array}$ \\
\hline Kleibergen-Paap Wald rk F statistic for IV in first stage & & 32.648 \\
\hline P-Value of Anderson-Rubin test & & 0.000 \\
\hline P-Value of Hansen J statistic & & 0.117 \\
\hline $\mathrm{N}$ & 333 & 333 \\
\hline Mean Dependent Variable & 84.384 & 84.384 \\
\hline Std. Dev. Dependent Variable & 111.852 & 111.852 \\
\hline
\end{tabular}

\section{B.4 Robustness of Results to Inclusion of Alternative Instruments}

I present OLS and IV results in Table B4 for the effect of PM10 pollution on asthma hospitalizations, estimated with varied sets of instruments. Column (1) corresponds to OLS results with various control variables, including year fixed effects, an annual trend, parish-level fixed effects, and weather control variables. Column (2) corresponds to the same control variable specifications for the IV regression with just the instrument natural gas prices for PM10 pollution. Column (3) reports the same control variable specifications with natural gas prices and barge calls as instruments for PM10 pollution. Column (4) corresponds 
to the same control variable specifications for the IV regression with natural gas prices, river barge calls, and river barge calls interacted with proximity to the port as instruments for PM10 pollution. Column (5) reports the IV results with natural gas prices, river barge calls, and natural gas prices interacted with proximity to the port as instruments for PM10 pollution. The IV regressions with varied instruments result in estimates that are largely stable. In particular, when IV results are just-identified (with natural gas prices as the single instrument, in Column (2)), the effect of PM10 pollution on asthma hospitalizations are only slightly smaller in magnitude than with the full set of instruments.

Table B4: Effects of Asthma from PM10 Concentration - Robust to Varied Instruments

\begin{tabular}{|c|c|c|c|c|c|}
\hline & (1) & $(2)$ & $(3)$ & (4) & $(5)$ \\
\hline Dependent variable: Asthma & OLS & 2SLS & 2SLS & 2SLS & 2SLS \\
\hline \multirow[t]{2}{*}{ Concentration } & $5.780759^{* * *}$ & $10.960294^{* * *}$ & $9.920914^{* * *}$ & $9.927030^{* * *}$ & $10.787094^{* * *}$ \\
\hline & $(1.239690)$ & $(3.402295)$ & $(2.340122)$ & $(2.571739)$ & $(2.462237)$ \\
\hline GDP & $\mathrm{Y}$ & $\mathrm{Y}$ & $\mathrm{Y}$ & $\mathrm{Y}$ & $\mathrm{Y}$ \\
\hline Annual Trend & $\mathrm{Y}$ & $\mathrm{Y}$ & $\mathrm{Y}$ & $\mathrm{Y}$ & $\mathrm{Y}$ \\
\hline Parish FE & $\mathrm{Y}$ & $\mathrm{Y}$ & $\mathrm{Y}$ & $\mathrm{Y}$ & $\mathrm{Y}$ \\
\hline \multirow[t]{2}{*}{ Weather } & $\mathrm{Y}$ & $\mathrm{Y}$ & $\mathrm{Y}$ & $\mathrm{Y}$ & $\mathrm{Y}$ \\
\hline & Instrument & & & & \\
\hline \multirow[t]{2}{*}{ Citygate } & & $0.57469^{* * *}$ & $0.83446^{* * *}$ & $0.00016^{* * *}$ & $0.00012^{* * *}$ \\
\hline & & 0.04037 & 0.05065 & 0.00003 & 0.00002 \\
\hline \multirow[t]{2}{*}{ Barge Calls } & & & $0.00012^{* * *}$ & $0.83616^{* * *}$ & $1.11932^{* * *}$ \\
\hline & & & 0.00002 & 0.05108 & 0.06545 \\
\hline \multirow[t]{2}{*}{ Proximity to Port X Barge Calls } & & & & $0.000000^{* *}$ & \\
\hline & & & & 0.000000 & \\
\hline \multirow[t]{2}{*}{ Proximity to Port X Citygate } & & & & & $0.001434^{* * *}$ \\
\hline & & & & & 0.000287 \\
\hline Kleibergen-Paap Wald rk F statistic for IV in first stage & & 202.623 & 139.075 & 91.918 & 156.464 \\
\hline P-Value of Anderson-Rubin test & & 0.001 & 0.000 & 0.000 & 0.000 \\
\hline P-Value of Hansen J statistic & & . & 0.445 & 0.595 & 0.163 \\
\hline $\mathrm{N}$ & 970 & 970 & 970 & 970 & 970 \\
\hline Mean Dependent Variable & 95.313 & 95.313 & 95.313 & 95.313 & 95.313 \\
\hline Std. Dev. Dependent Variable & 135.103 & 135.103 & 135.103 & 135.103 & 135.103 \\
\hline \multicolumn{6}{|c|}{$\begin{array}{l}\text { Notes: The coefficient estimates reported in Column (1) are the OLS results with year fixed effects, an annual trend, parish-level fixed effects, and weather control } \\
\text { variables. Column (2) reports the 2SLS results for the same specification, with only natural gas prices as an instrument for PM10 pollution. Column (3) reports } \\
\text { the } 2 \text { SLS results for the same specification, with natural gas prices and river barge calls as instruments for PM10 pollution. Column }(4) \text { reports the } 2 \text { SLS results } \\
\text { for the same specification, with natural gas prices, river barge calls, and the interaction of river barge calls and a parish's proximity to the Port of South Louisiana } \\
\text { as instruments for PM10 pollution. Column (5) reports the } 2 \text { SLS results for the same specification, with natural gas prices, river barge calls, and the interaction } \\
\text { of natural gas prices and a parish's proximity to the Port of South Louisiana as instruments for PM10 pollution. First-stage results are reported in the bottom } \\
\text { panel of the table, along with the Kleibergen-Paap Wald Statistic, the p-value for the Anderson-Rubin test, and the p-value for the Hansen J statistic. Errors are } \\
\text { clustered at the parish-level. } * \mathrm{p}<0.10,{ }^{* *} \mathrm{p}<0.05, * * * \mathrm{p}<0.01 \text {. }\end{array}$} \\
\hline
\end{tabular}

